\title{
Het Commissiepakket 'betere regelgeving voor betere resultaten' en het nieuwe Interinstitutioneel Akkoord beter wetgeven: Too little, too late?
}

\author{
Prof. mr. L.A.J. Senden*
}

De EU krijgt nog steeds veelal gestalte via de uitoefening van de wetgevende bevoegdheden die ze in de loop der tijd heeft gekregen. De toenemende kritische houding van de burger tegenover de Unie - niet alleen in het Verenigd Koninkrijk, maar ook elders - heeft druk gezet op zowel de lidstaten als de Europese instellingen om de manier waarop die bevoegdheden worden uitgeoefend opnieuw te doordenken. Als zodanig kan de hernieuwde focus op 'betere regelgeving' goed worden begrepen. Het nieuwe Uniebeleid roept echter wel de vraag op, betere regelgeving voor wie? Die vraag heeft na het Britse 'nee' tegen het Unielidmaatschap nog meer lading gekregen.

BR-Mededeling (COM (2015)215 final), BR-richtsnoeren (SWD (2015)111 final), REFIT (SWD (2015)110 final), Interinstitutioneel Akkoord, PbEU 2016, L 123.

\section{Inleiding en achtergrond}

Sinds medio jaren negentig staat het thema van betere regelgeving al op de Europese agenda, ${ }^{1}$ maar met het aantreden van de Commissie Juncker in zomer 2014 is 'betere regelgeving' (hierna: BR) een uitdrukkelijk speerpunt geworden van het Commissiebeleid. De hernieuwde aandacht hiervoor is aangewakkerd door de discussie die premier Cameron in januari 2013 in het Verenigd Koninkrijk entameerde over de bevoegdheden van de Unie en zijn pleidooi voor minder bemoeienis van de

* Prof. mr. L.A.J. (Linda) Senden is hoogleraar Europees recht aan de Universiteit Utrecht en verbonden aan het RENFORCE onderzoekscentrum. Ook is zij redactielid van NtEr.

1. Zie daarover bijvoorbeeld R. Baldwin, 'Tensions Aboard the Enterprise', in: S. Weatherill (red.), Better Regulation, Oxford/Portland: Hart Publishing 2007, p. 29-30.
Unie op bepaalde terreinen, een 'competences review' en deregulering. Daarin kreeg hij bijval van de Nederlandse premier Rutte, die ook een subsidiariteitsreview aankondigde. $^{2}$ Maar ook andere lidstaten, waaronder Polen, drongen aan op deregulering en het beperken van administratieve lasten. ${ }^{3}$ In zijn Conclusies van oktober 2013 stelde de Europese Raad dat regelgeving op Unieniveau noodzakelijk is ter verwezenlijking van de beleidsdoelstellingen van de EU, waaronder de goede werking van de interne markt, en dat dat 'moet worden bereikt met een maximum aan transparantie en eenvoud en een minimum aan kosten, zonder uit het oog te verliezen dat de consumenten, de gezondheid, het milieu en de werknemers naar behoren moeten worden beschermd'. Hij sprak zijn waardering uit voor het programma van gezonde regelgeving (REFIT) van de Commissie en het daarmee ingezette beleid van vermindering van regeldruk, maar riep de Commissie tegelijkertijd op om met verdere, substantiële voorstellen te komen. ${ }^{4}$ Dit vormde een duidelijk politiek signaal voor de nieuwe Commissie om een koers te varen die zowel bescheidenheid en terughoudendheid zou moeten laten zien alsook tot effectieve(re) regelgeving en resultaten zou moeten leiden.

In de politieke beleidslijnen van de Commissie die Juncker in juli 2014 in het Europees Parlement presenteerde, was de focus erg gekleurd door deze achtergrond want sterk ingestoken op ondernemersbelangen: het 'creëren van een regelgevingsklimaat dat bevorderlijk is voor ondernemerschap en het scheppen van banen' en dat

2. Zie hierover A. van den Brink, 'De begrenzing van de Europese Unie als een gedeelde constitutionele opdracht', SEW juni 2014, nr. 6, p. 99.

3. Zie bijvoorbeeld <https://euobserver.com/news/121908> en <www. eecpoland.eu/2016/en/news/deregulation-and-new-markets-8211cures-for-the-crisis-in-europe, 198066.html>.

4. Conclusies van de Europese Raad, 24/25 oktober 2013, EUCO 169/13, par. 29-32. 
ervoor zorgt dat innovatie en competitiviteit niet worden verstikt met te veel en te gedetailleerde regeltjes, met name waar het gaat om het midden- en kleinbedrijf,' kortom dat het mkb wordt 'bevrijd van overmatige en overdreven regelgeving'. 5 Een specifieke EUCommissaris werd belast met Betere Regelgeving, Frans Timmermans, tevens eerste vicevoorzitter van de Europese Commissie. Bij de presentatie van het 'Betere regelgeving voor betere resultaten'-pakket in mei 2015 stelde hij dat betere regelgeving niet gaat over meer of minder EU-regels of over het ondermijnen van onze hoge sociale en milieustandaarden, volksgezondheid en fundamentele rechten, maar om het verzekeren dat de Unie op de meest efficiënte wijze de ambitieuze beleidsdoelen realiseert die zij zichzelf heeft gesteld. ${ }^{6}$ In de BRMededeling, die de grondslag vormt van het algehele BR-beleid, zien we pas in zoveel woorden de Commissiedoelstelling terug dat dit beleid ook moet bijdragen aan versterking van het burgervertrouwen in de EU:

'De Commissie is vastbesloten om veranderingen aan te brengen in wat de Europese Unie doet en hoe zij dit doet. De EU, haar instellingen en haar rechtscorpus moeten ten dienste staan van burgers en ondernemingen, die dat in hun dagelijks leven en bij hun dagelijkse activiteiten moeten kunnen vaststellen. Wij moeten hun vertroumen in ons vermogen om resultaten te boeken herwinnen.' [mijn nadruk]

Hierna wordt eerst ingegaan op de kernelementen van het Commissie BR-pakket en van het nieuwe Interinstitutioneel Akkoord inzake beter wetgeven (hierna: IIA) dat in april jl. werd gepresenteerd en dat het sluitstuk vormt van het BR-pakket. Deze inventariserende beschrijving vormt de basis voor een kritische beoordeling; wat kan als centrale focus en doelstelling, vernieuwing en vooruitgang worden gezien in dit beleid en het Akkoord en waar heeft men kansen laten liggen, onder meer vanuit een bredere reflectie over de betekenis die aan het begrip 'betere regelgeving' kan worden gegeven, zeker ook in de Uniecontext? De bijdrage besluit met enkele slotoverwegingen.

\section{Een meer integrale Commissieaanpak}

Op 20 mei 2015 ontvouwde de Commissie haar BRplannen in de Mededeling over betere regelgeving voor betere resultaten - een EU-agenda. ${ }^{7}$ Het hele BR-pakket omvatte daarnaast nog drie andere kerndocumenten:

5. J.C. Juncker, 'Een nieuwe start voor Europa: mijn agenda voor banen, groei, billijkheid en democratische verandering. Politieke beleidslijnen voor de volgende Europese Commissie, Straatsburg', 15 juli 2014, p. 5. Te vinden via: <https://ec.europa.eu/priorities/sites/beta-political/files/ pg_nl.pdf>.

6. Zie <http://europa.eu/rapid/press-release_IP-15-4988_nl.htm>, laatst geraadpleegd op 29 juni 2016

7. $\operatorname{COM}(2015) 215$ final. de BR-Richtsnoeren, ${ }^{8}$ de BR-Toolbo $x^{9}$ en de REFIT state of play en outlook, ${ }^{10}$ in totaal meer dan 650 pagina's. Daarmee beoogde de Commissie niet alleen alle beginselen, regels, middelen en procedures die ze de laatste jaren heeft ontwikkeld bij elkaar te brengen, maar ook verder te gaan. Op 21 mei publiceerde ze het voorstel voor een herzien Interinstitutioneel Akkoord Beter Wetgeven tussen het Europees Parlement, de Raad en de Commissie.

De belangrijkste uitgangspunten die de Commissie in de Mededeling heeft geformuleerd om het bovenstaande doel van BR te bereiken kunnen worden samengevat in termen van (i) institutioneel belang, (ii) resultaat en (iii) proces van BR.

(i) Institutioneel belang

Het zijn de uitgezette politieke prioriteiten die allereerst bepalend zijn voor nieuwe Commissie-initiatieven, met de nadruk op zaken die niet alleen door de lidstaten kunnen worden gerealiseerd, zoals een investeringsplan voor het stimuleren van werkgelegenheid en groei, betaalbare, gegarandeerde en duurzame energievoorziening, interneveiligheidsagenda, migratie en digitale interne markt. BR is in dit verband slechts een hulpmiddel dat een basis biedt voor het maken van tijdige en gedegen beleidsmatige besluiten en geen vervanging van politieke besluitvorming, zo stelt de Commissie. Tegelijkertijd onderstreept ze echter ook het belang van een gedeeld commitment en verantwoordelijkheid van alle betrokken instellingen en van elke lidstaat voor de BRagenda om daadwerkelijke verandering te kunnen bewerkstelligen.

(ii) Resultaat

Benadrukt wordt ook dat BR niet gaat over meer of minder EU-wetgeving en niet over het deprioritiseren van bepaalde beleidsterreinen of het aantasten van de waarden waarvoor de Unie staat, maar om regelgeving die zijn doel dient, duidelijke voordelen biedt voor burgers, bedrijfsleven en de maatschappij als geheel, die modern, effectief, proportioneel, operationeel, voorspelbaar en zo eenvoudig mogelijk is, zekerheid biedt en elke onnodige belasting vermijdt. Er moet duidelijkheid zijn over de doelstellingen van beleid en dat gekozen oplossingen de beste en minst belastende zijn ter realisering daarvan. Zowel regelgevende als goed vormgegeven, niet-regelgevende middelen moeten daarbij in aanmerking worden genomen, en ook verbeteringen in de implementatie en handhaving van bestaande wetgeving. In het bijzonder dient ook het Think Small First-beginsel te worden toegepast, waarbij de belangen van het mkb in aanmerking worden genomen bij de ontwikkeling en vormgeving van beleid. Een lichter regime voor het mkb moet worden overwogen en ook of micro-

8. Commission Staff Working Document Better Regulation Guidelines, SWD (2015)111 final;

9. <http://ec.europa.eu/smart-regulation/guidelines/docs/br_toolbox_en. pdf>

10. Commission Staff Working Document Regulatory Fitness and Performance Programme (REFIT): State of Play and Outlook, SWD (2015)110 final. 
ondernemingen geheel vrijgesteld kunnen worden van bepaalde regels.

(iii) Proces

Openheid en transparantie van het besluitvormingsproces worden ook gezien als kernelementen van BR en deze moeten worden verzekerd via meer consultatie. De gedachte is dat dit niet alleen een betere verantwoording van beleid verzekert, maar ook bijdraagt aan de effectiviteit ervan doordat het zo kan worden gebaseerd op het best beschikbare bewijs. De EU moet ook beter uitleggen wat ze doet en waarom door een betere memorie van toelichting en door eerlijk te zijn over hoe goed/slecht bepaalde oplossingen werken. Alle significante impacts - positief of negatief, te kwantificeren of niet - moeten worden geanalyseerd en in aanmerking worden genomen. De Mededeling legt ook nadruk op beoordeling en evaluatie tijdens de gehele beleidscyclus, om ervoor te zorgen dat beleid zijn doel blijft dienen. Dit betekent onder meer terugkijken of ingevoerd beleid de gewenste impact heeft gehad en, waar mogelijk, lasten verlichten zonder afbreuk te doen aan de beleidsambitie. Dit vraagt om een inclusieve aanpak, waarbij het nieuwe REFITstakeholderplatform een belangrijke rol speelt (nader hierover in de volgende paragrafen). Via een speciaal 'Verminder de regeldruk! - Laat uw stem horen!'-formulier kan elke burger direct bij de Commissie onder de aandacht brengen hoe Unieregels efficiënter en effectiever gemakt kunnen worden. ${ }^{11}$ In dit verband is ook van belang dat de Raad voor effectbeoordeling inmiddels al is vervangen door de door de Commissie voorgestelde Raad voor regelgevingstoetsing, die een breder mandaat heeft; deze onderzoekt en adviseert niet alleen over effectbeoordelingen, maar ook over grote evaluaties en 'fitness checks' van reeds bestaande wetgeving. Verder is deze Raad ook onafhankelijker geworden doordat deze los van de beleidsdepartementen functioneert en ook drie leden heeft van buiten de Commissie en commissieleden die fulltime voor de raad werken en geen andere beleidsverantwoordelijkheden hebben. Echter, de voorzitter van de Raad is een van de directeuren-generaal van de Commissie. ${ }^{12}$

De BR-richtsnoeren gaan in acht hoofdstukken nader in op wat BR is en wat de essentiële elementen zijn ter realisering daarvan, in het bijzonder: planning en politieke validatie; effectbeoordeling; de voorbereiding van voorstellen, implementatie en omzetting; monitoring/toezicht; evaluatie en fitness checks; en stakeholderconsultatie. De richtsnoeren moeten overigens niet als absolute, procedurele normen worden gezien die altijd en overal moeten worden toegepast. Er behoort met een zekere flexibiliteit mee om te worden gesprongen om zo ruimte te geven om op specifieke (crisis)situaties in te kunnen spelen, waar dan wel een rechtvaardiging voor moet worden aangegeven. Het laatste hoofdstuk van de richtsnoeren geeft een voorzet van wat er in de BRToolbox kan worden gevonden, waarin in 414 pagina's

11. Zie <http://ec.europa.eu/smart-regulation/refit/simplification/consulta tion/consultation_nl.htm\#up>, laatst geraadpleegd op 29 juni 2016.

12. Zie <http://ec.europa.eu/smart-regulation/impact/iab/iab_nl.htm>. maar liefst 59 'werktuigen' zijn opgenomen voor de operationalisering van de BR-richtsnoeren door de Commissieambtenaren. Deze hebben bovenal betrekking op hoe effectbeoordelingen, evaluaties en fitness checks moeten worden uitgevoerd en hoe in dat verband allerlei impacts kunnen worden vastgesteld, waaronder interne markt-, concurrentie-, mensenrechten-, consumenten-, gezondheids- en territoriale effecten, alsook kostenbatenanalyses kunnen worden verricht.

\section{De inhoud van het Interinstitutioneel Akkoord Beter Wetgeven}

Zoals gezegd vormt het nieuwe IIA het sluitstuk van het BR-pakket van de Commissie. Het politieke momentum voor het sluiten van dit Akkoord blijkt uit het feit dat het onderhandelingsproces slechts een half jaar bestrijkt en dat ook goedkeuring van het EP en de Raad snel is bereikt. $\mathrm{Na}$ intensieve onderhandelingen met het $\mathrm{EP}$ gaf de Europese Raad op 15 december 2015 zijn goedkeuring aan een aangepast voorstel. ${ }^{13}$ Op 9 maart nam het Europees Parlement het Akkoord aan en de Raad van Ministers deed dat op 15 maart. Het is op 13 april ondertekend en op die dag in werking getreden en op 16 mei in het Publicatieblad bekendgemaakt. ${ }^{14}$ Het IIA (en zijn bijlagen) vervangt het IIA Beter Wetgeven uit 2003, de Interinstitutionele Aanpak Gemeenschappelijke effectbeoordelingen uit 2005 en het Gezamenlijk Akkoord over gedelegeerde handelingen uit 2011. Het beslaat een negental paragrafen, waarvan hieronder de meest essentiële en vernieuwende aspecten in kaart worden gebracht.

De eerste paragraaf, die de gemeenschappelijke verbintenissen en doelstellingen betreft, kan als de grondslag voor de algehele interinstitutionele visie worden gezien en wordt hier om die reden in zijn geheel geciteerd:

'1. Hierbij komen de drie instellingen overeen om door middel van een aantal initiatieven en procedures die in dit akkoord zijn omschreven beter wetgeven na te streven.

2. Wijzend op het belang dat zij aan de communautaire methode hechten, komen de drie instellingen overeen om bij de uitoefening van hun bevoegdheden en overeenkomstig de in de Verdragen neergelegde procedures, algemene Unierechtelijke beginselen, zoals democratische legitimiteit, subsidiariteit en evenredigheid, en rechtszekerheid, in acht te zullen nemen. Voorts komen zij overeen om bij de opstelling van Uniewetgeving eenvoud, duidelijkheid en cohe-

13. Zie ook de Conclusies van de Europese Raad inzake 'Better regulation to strengthen competitiveness' van 26 mei 2016, <www.consilium.europa. $\mathrm{eu} / \mathrm{nl} / \mathrm{press} /$ press-releases/2016/05/26-conclusions-betterregulation/>, laatst geraadpleegd op 29 juni 2016.

14. PbEU 2016, L 123. 
rentie te bevorderen, alsook maximale transparantie van het wetgevingsproces.

3. De drie instellingen komen overeen dat Uniewetgeving begrijpelijk en duidelijk moet zijn, burgers, overheidsdiensten en bedrijven in staat moet stellen gemakkelijk hun rechten en verplichtingen te begrijpen, passende voorschriften inzake rapportage, monitoring en evaluatie moet bevatten, overregulering en administratieve lasten moet vermijden en praktisch uitvoerbaar moet zijn.'

Opmerkelijk in deze formulering is allereerst dat de focus - net als in het oude IIA - nog steeds is gericht op 'beter wetgeven' en daarmee bovenal op het proces van wetgeven, ook al worden er ook eisen geformuleerd ten aanzien van het te bereiken eindresultaat en product. Dit bevestigt de beperkte focus zoals die ook al uit de titel van het IIA zelf blijkt, en dat er dus ook sprake is van een weloverwogen politieke keuze om niet te spreken van betere regelgeving in een bredere betekenis (zie nader hierna). Dit wordt ook onderstreept door de nadruk die op de communautaire methode wordt gelegd. Nieuw ten opzichte van het eerdere IIA is wel dat burgers, overheidsdiensten en bedrijven nu als uitdrukkelijke adressaten van de BR-exercitie worden benoemd en dat het een uitdrukkelijk doel is om overregulering en administratieve lasten te vermijden. Dit laatste stond overigens niet in het voorstel van de Commissie, maar is later in het onderhandelingsproces door het EP en de Raad toegevoegd en ook gepresenteerd als een belangrijke rode draad van de hele exercitie. Gegeven de in de inleiding geschetste achtergrond verbaast dit niet (zie nader hierna).

Paragraaf 2 brengt belangrijke vernieuwingen in de interinstitutionele dialoog en procedures aangaande de programmering van metgeving, die aanzienlijk verder gaan dan de Commissie in haar voorstel had voorzien. Wat de meerjarige programmering betreft, nemen de drie instellingen bij het aantreden van een nieuwe Commissie gezamenlijke conclusies aan waarin de beleidsdoelstellingen en -prioriteiten voor de nieuwe mandaatperiode worden aangegeven en, waar mogelijk, een indicatief tijdschema. Deze conclusies worden tussentijds geëvalueerd en kunnen zo nodig worden bijgestuurd. Voordat ze haar jaarlijkse werkprogramma vaststelt, treedt de Commissie in - bilaterale - dialoog met het EP en de Raad en 'houdt ze naar behoren rekening' met de door beide instellingen geformuleerde standpunten. $\mathrm{Na}$ vaststelling van het werkprogramma stellen ze een gezamenlijke verklaring vast over jaarlijkse interinstitutionele programmering, waarin ruime doelstellingen en prioriteiten voor het komende jaar worden vermeld en onderwerpen 'van groot politiek belang' worden aangeduid die in het wetgevingsproces prioritair moeten worden behandeld. De uitvoering van de gezamenlijke verklaring wordt regelmatig gemonitord en in het voorjaar nemen de drie instellingen deel aan debatten in het EP en/of de Raad over de uitvoering ervan.
De Commissie moet verder niet alleen haar belangrijke voorstellen voor wetgevingshandelingen en niet-wetgevingshandelingen voor het volgende jaar vermelden, maar ook intrekkingen, herschikkingen, vereenvoudigingen en intrekkingen van voorstellen. Voor intrekking moet ze de redenen aangeven. Voorstellen voor Uniehandelingen die het EP of de Raad op grond van artikel 225 resp. 214 VWEU hebben gedaan, moet de Commissie 'onmiddellijk en uitgebreid' onderzoeken en ze moet binnen drie maanden aangeven welk gevolg ze daaraan wil geven. Besluit ze geen voorstel in te dienen, dan moet ze een uitvoerige motivering verstrekken en ingaan op eventuele punten die de medewetgevers hebben opgeworpen met betrekking tot de Europese meerwaarde en de kosten van geen Europa. Waar passend geeft ze ook een analyse van mogelijke alternatieven. Het EP en de Raad moeten ook regelmatig geinformeerd worden over de Commissieplanning, eventuele vertragingen en over de uitvoering van haar werkprogramma. De Raad heeft op 11 maart al praktische regelingen getroffen met betrekking tot de jaarlijkse programmering, met name het te volgen tijdschema en bijbehorende stappen. ${ }^{15}$

In de derde paragraaf wordt voorzien in drie instrumenten voor beter metgeven: effectbeoordeling, raadpleging van publiek en belanghebbenden en feedback en evaluatie van bestaande wetgeving. Ten aanzien van effectbeoordelingen wordt voorop gesteld dat deze niet in de plaats treden van de politieke besluiten van het democratische besluitvormingsproces, ze niet mogen leiden tot onnodige vertragingen in het wetgevingsproces, noch mogen afdoen aan de mogelijkheid voor de medewetgevers om wijzigingen voor te stellen. Effectbeoordelingen worden wel al lang door de Commissie uitgevoerd, maar niet door het EP en de Raad; de Commissie deed tussen 2007 en 2014 meer dan 700 effectbeoordelingen, tegenover 20 door het EP in diezelfde periode en geen enkele door de Raad. ${ }^{16}$ Beide instellingen hebben ook nagelaten de effectbeoordelingen van de Commissie mee te nemen in hun beschouwing van Commissievoorstellen. Het kan dan ook als winst worden gezien dat het IIA nu stelt dat het EP en de Raad bij de behandeling van wetgevingsvoorstellen 'ten volle rekening [houden] met de beoordeling van de Commissie' en dat zij deze in de regel als uitgangspunt nemen voor hun verdere werkzaamheden. 'Wanneer zij dit passend en noodzakelijk achten voor het wetgevingsproces', stellen beide instellingen zelf effectbeoordelingen op over hun 'wezenlijke wijzigingen' van het Commissievoorstel. Elke instelling moet echter zelf definiëren wat zij onder een dergelijke 'wezenlijke' wijziging verstaat. De instellingen wisselen beste praktijken en methodes uit om hun effectbeoordelingen te verbeteren en om samenhang van de algehele werkzaamheden te verbeteren, maar er is dus nadrukkelijk niet gekozen voor een gezamenlijke interinstitutionele effectbeoordeling.

15. <http://data.consilium.europa.eu/doc/document/ST-6879-2016-INIT/ $\mathrm{nl} / \mathrm{pdf}>$, laatst geraadpleegd op 29 juni 2016

16. Zie de Commissiemededeling, COM (2015)215 final. 
Vóór de vaststelling van een voorstel, en ook in het kader van haar effectbeoordelingen, dient de Commissie op open en transparante wijze raadplegingen van het publiek en belanghebbenden te houden, waarbij zij verzekert dat de wijze van uitvoering en termijnen van die raadplegingen voor een zo breed mogelijke deelneming zorgen. Voorts informeert de Commissie het EP en de Raad over haar meerjarige planning voor evaluaties van bestaande wetgeving en houdt ze daarbij 'zo veel mogelijk rekening met hun verzoeken om diepgaande evaluatie van specifieke beleidsterreinen of rechtshandelingen'. Evaluaties moeten de basis vormen voor effectbeoordelingen van opties voor verdere acties, en zijn gebaseerd op doelmatigheid, doeltreffendheid, relevantie, samenhang en meerwaarde. Indien nodig worden daartoe in de wetgeving voorschriften opgenomen voor rapportering, monitoring en evaluatie, 'waarbij echter overregulering en administratieve lasten, in het bijzonder voor de lidstaten, worden vermeden'. Waar passend kunnen meetbare indicatoren worden opgenomen in de wetgeving, en overwegen de drie instellingen systematisch het gebruik van evaluatieclausules in wetgeving en of zij de toepassing van bepaalde wetgeving tot een vaste periode beperken.

Ten aanzien van het gebruik van metgevingsinstrumenten bevat paragraaf 4 van het IIA niet heel veel nieuws en wordt er weinig opzienbarend op gewezen dat de Commissie 'naar behoren rekening [dient] te houden met het verschil in aard en in gevolgen tussen verordeningen en richtlijnen' en dat de Commissie haar voorstellen moet rechtvaardigen in het licht van de subsidiariteits- en evenredigheidsbeginselen en aan moet geven waarom ze verenigbaar zijn met grondrechten. Daarnaast wisselen de drie instellingen van gedachten over een beoogde wijziging van de rechtsgrondslag wanneer dat ertoe leidt dat een bijzondere wetgevingsprocedure of een nietwetgevingsprocedure in de plaats van de gewone wetgevingsprocedure wordt toegepast.

Paragraaf 5 over gedelegeerde en uitvoeringshandelingen is (vanzelfsprekend) geheel nieuw, nu deze handelingen pas bij het Verdrag van Lissabon zijn ingevoerd. 'Indien zij op doelmatige en transparante wijze en in gerechtvaardigde gevallen worden gebruikt', vormen zij volgens de drie instellingen 'wezenlijke instrumenten voor beter wetgeven, daar zij bijdragen aan eenvoudige, bijgewerkte wetgeving en aan een doelmatige en snelle uitvoering daarvan'. Van bijzonder belang is de 'Gezamenlijke Afspraak' die het EP, de Raad en de Commissie hebben gemaakt, die de Commissie ertoe verplicht om, voorafgaand aan de vaststelling van gedelegeerde handelingen, raadplegingen te houden van deskundigen van de lidstaten en van het publiek. Deze Afspraak is aan het IIA gehecht. Daarmee is een controversiële kwestie die ook interinstitutionele spanningen met zich bracht, beslecht ten gunste van de Raad c.q. de lidstaten. ${ }^{17} \mathrm{Bij}$ de voor- bereiding van ontwerpuitvoeringshandelingen moet de Commissie ook deskundigengroepen of specifieke belanghebbenden of het publiek raadplegen telkens wanneer een ruimere expertise nodig is. Deskundigen van het EP en de Raad hebben ook systematisch toegang tot de deskundigengroepen van de Commissie waarvoor deskundigen van de lidstaten zijn uitgenodigd en die de voorbereiding van gedelegeerde handelingen betreffen. Ook zullen de drie instellingen nu onverwijld onderhandelingen aangaan om ter aanvulling van de Gezamenlijke Afspraak niet-bindende criteria vast te stellen voor het gebruik van gedelegeerde en uitvoeringshandelingen $^{18}$ en zullen ze een gemeenschappelijk functioneel register van gedelegeerde handelingen instellen.

Ten aanzien van de transparantie en coördinatie van het petgevingsproces verbinden de drie instellingen in paragraaf 6 zich ertoe elkaar, onder meer via een onderlinge dialoog, regelmatig op de hoogte te houden van hun werkzaamheden, zowel van de lopende onderlinge onderhandelingen alsook van de feedback die zij mogelijk van belanghebbenden ontvangen. Ook wordt benadrukt dat het EP en de Raad hun rol van medewetgever op voet van gelijkheid uitoefenen, dat ze nog voor de aanvang van de interinstitutionele dialoog nauwe contacten onderhouden, ze zorgen voor een betere afstemming van de behandeling van wetgevingsvoorstellen, inspanningen coördineren voor het versnellen van het wetgevingsproces, zorgen voor transparantie van het wetgevingsproces, inclusief een 'passende afhandeling van trilaterale onderhandelingen', verbetering van de communicatie naar het publiek tijdens de gehele wetgevingscyclus en een gemeenschappelijk database zullen opzetten om de traceerbaarheid van de diverse stappen in die cyclus te bevorderen.

In paragraaf 7 over de uitvoering en toepassing van Uniemetgeving benadrukken de instellingen de noodzaak van een snelle en correcte toepassing van Unierecht in de lidstaten. De lidstaten worden ook 'verzocht' het publiek duidelijk te informeren over door hen genomen maatregelen ter omzetting of uitvoering van Uniewetgeving of ter uitvoering van de Uniebegroting. Wanneer de lidstaten bij de omzetting van richtlijnen elementen toevoegen in hun interne recht die 'op geen enkele wijze verband houden met die Uniewetgeving' dan moeten deze in de omzettingsmaatregel of in daarmee verband houdende documenten herkenbaar worden gemaakt. Het Commissievoorstel ging op dit punt wezenlijk verder en beoogde lidstaten de verplichting op te leggen een effectbeoordeling uit te laten voeren wanneer ze elementen toevoegen die verder gaan dan de richtlijn vereist. De lidstaten vonden dit duidelijk een brug te ver en hebben dit teruggebracht tot een informatiebepaling, waarbij zich overigens wel de vraag opdringt om wat voor elementen het precies gaat, met andere woorden: wat houdt 'op geen enkele wijze verband houden' in het
17. Zie bijvoorbeeld T. Christiansen en M. Dobbels, 'Interinstitutional Tensions in the New System of Delegation of Powers', in: C.F. Bergstrom en D. Retling (red.), Rulemaking by the European Commission, The New System for Delegation of Powers, Oxford: Oxford University Press 2016, p. 87-104
18. Zie over het gebruik van beide typen handelingen de eerdere bijdrage van A. van den Brink en $\mathrm{H}$. Van Meerten, 'EU-bestuurlijke regelgeving in de praktijk: het IORP-richtlijnvoorstel als voorbeeld', NtEr 2015/4, p. $133-140$ 
concrete geval in? Deze informatie zal worden opgenomen in het jaarlijkse verslag van de Commissie inzake de toepassing van de Uniewetgeving. De lidstaten worden ook verzocht om met de Commissie samen te werken bij het verzamelen van de informatie en de gegevens die nodig zijn voor de monitoring en de evaluatie van de uitvoering van Uniewetgeving.

Met betrekking tot het onderwerp van vereenvoudiging verbinden de instellingen zich in paragraaf 8 ertoe vaker gebruik te maken van de wetgevingstechniek van herschikking voor het wijzigen van bestaande wetgeving. 'Om overregulering en administratieve lasten te vermijden en de doelstellingen van de Verdragen te verwezenlijken', verbinden zij zich er verder ook toe 'de efficiëntste regelgevingsinstrumenten, zoals harmonisering en wederzijdse erkenning, te bevorderen'. De Commissie zal in het kader van haar REFIT-programma ${ }^{19}$ jaarlijks een overzicht presenteren, waaronder een lastenoverzicht, van de resultaten die de Unie heeft geboekt ten aanzien van vereenvoudiging, het tegengaan van overregulering en verminderen van administratieve lasten. Waar mogelijk zal de Commissie deze vermindering van afzonderlijke voorstellen of rechtshandelingen kwantificeren en reductiedoelstellingen vaststellen, ook voor specifieke sectoren.

Paragraaf 9 voorziet erin dat de uitvoering van het akkoord niet alleen op politiek niveau wordt gemonitord, maar ook door de interinstitutionele coördinatiegroep.

\section{Beoordeling}

Gegeven al deze specifieke aspecten van het BR-beleid en het IIA, wat kan als vernieuwing c.q. winst worden beschouwd, wat als tekortkoming c.q. gemiste kans daarin? Deze beoordeling volgt hieronder aan de hand van drie thema's die m.i. als de kern kunnen worden gezien van het aangenomen beleid: allereerst het belang dat aan gedeelde verantwoordelijkheid wordt gehecht, ten tweede de boventoon van een constitutionele, geproceduraliseerde insteek en ten derde - dit is tegelijkertijd het meest fundamentele kritiekpunt - de beperkte en eenzijdige inhoudelijke en instrumentele opvatting van BR. Daarbij worden ook kanttekeningen in aanmerking genomen die van de kant van de Nederlandse regering en van het parlement zijn gemaakt, onder meer in een brief van de Eerste Kamer aan de Commissie waarin de $\mathrm{SP}$ een aantal vragen en opmerkingen naar voren heeft gebracht. ${ }^{20}$

\section{Gedeelde verantwoordelijkheid}

Een grondgedachte die naar voren komt in het IIA is die van een gedeelde verantwoordelijkheid, waarbij de

19. REFIT staat voor Regulatory Fitness and Performance; gezonde en resultaatgerichte regelgeving. Zie <http://ec.europa.eu/smart-regulation/ refit/index_en.htm> voor meer informatie omtrent lopende acties.

20. Zie <www.eerstekamer.nl/eu/behandeling/20151009/brief_aan_de_ europese_commissie/info>, laatst geraadpleegd op 2 juli 2016. Zie voor alle stappen in de Kamer in de behandeling hiervan: <www. eerstekamer.nl/eu/edossier/e150011_commissiemededeling_betere $>$. nadruk allereerst ligt op een horizontale, tussen de Europese wetgevingsinstellingen gedeelde verantwoordelijkheid voor zowel het proces van beter wetgeven alsook het eindproduct daarvan. Meer dan voorheen het geval was, wordt er voorzien in allerlei procedures die ervoor moeten zorgen dat de instellingen zich meer aan elkaar gelegen laten liggen in dit proces en tot een betere samenwerking en afstemming komen (zie nader hierna in de paragraaf 'Een sterk constitutionele, geproceduraliseerde insteek').

Uit het IIA komt echter ook een beeld naar voren van een verticale, van de Unie met de lidstaten gedeelde verantwoordelijkheid. Dat blijkt uit de nadruk die het IIA nu niet alleen legt op een snelle en correcte uitvoering en toepassing van Uniewetgeving, maar ook - voor het eerst - op nationale 'gold plating' activiteiten. Er wordt een duidelijk signaal afgegeven dat wanneer lidstaten in hun implementatiewetgeving verder gaan dan de Uniewetgeving vereist, lidstaten dat naar buiten toe zichtbaar maken. Dit zou ertoe bij moeten dragen dat het beeld in het politieke en publieke debat wordt bijgesteld, dat 'Brussel' allerlei regels oplegt waar die in werkelijkheid het gevolg zijn van nationale, aanvullende beleidskeuzes. $^{21}$ Daarmee blijft de discretionaire beleidsruimte van lidstaten om dergelijke keuzes te maken nog wel intact en ook hun institutionele autonomie om zelf te bepalen hoe om te gaan met de omzettingsplicht. Dit heeft de Commissie bevestigd in respons op de voornoemde brief van de Eerste Kamer. ${ }^{22}$ Overigens stelt in Nederland richtsnoer 331 van de Aanwijzingen voor de Regelgeving dat omzetting zich moet beperken tot datgene wat strikt noodzakelijk is, vanuit overwegingen van tijdige implementatie en van behoud van concurrentiepositie van Nederlandse ondernemingen. ${ }^{23}$ Een saillant gegeven in het licht van de Brexitdiscussie en de nadruk die premier Cameron legde op de noodzaak overregulering aan te pakken, is dat het Britse Institute of Directors in 2013 nog concludeerde dat het VK niet genoeg deed om gold-plating te bestrijden. ${ }^{24}$

Het Unieniveau en het lidstatelijk niveau worden in het BR-beleid nu echter niet enkel meer op deze 'klassieke' wijze met elkaar verbonden, waarbij het ene niveau verantwoordelijk wordt geacht voor de regelstelling en het andere niveau voor de omzetting, toepassing en handhaving daarvan. Er is nu veeleer sprake van een circulaire opvatting van de verbinding tussen beide niveaus, door de nadruk die wordt gelegd op het realiseren van beter wetgeven in het kader van de hele beleidscyclus, van agendering, voorbereiding en besluitvorming tot omzetting, toepassing en handhaving. Dit wil zeggen, er is nu sprake van een duidelijk bewustzijn dat beter wetgeven

21. Zie hierover J. Stoop, 'Nationale Koppen op EU-regelgeving; een relevante discussie?', NtEr 2012/6, p. 229-237.

22. Kamerstukken / 2015/16, 34 317, nr. C.

23. Zie L. Squintani, 'The Dutch policy on gold-plating and the transposition of Directive 2008/98/EC on waste, ELNI Review 2013, 1+2, p. 45.

24. P. Sack, 'The Midas Touch: Gold-plating of EU employment directives in the UK law', IoD Policy Paper, 10 juni 2013, te raadplegen op <www. iod.com/influencing/policy-papers/regulation-and-employment/themidas-touch-goldplating-of-eu-employment-directives-in-uk-law $>$. 
niet zozeer een lineair proces is waarbij de Unie de opsteller en 'zender' van regels is naar de lidstaten en deze slechts de ontvangers en toepassers daarvan vormen, maar veeleer een circulair proces waarbij zowel Unie als nationale instellingen bij de verschillende onderdelen van de cyclus zijn betrokken. ${ }^{25}$ Dat blijkt met name ook uit het belang dat nu wordt gehecht aan het instrument van evaluatie van wetgeving en de verplichtingen die op lidstaten worden gelegd om te rapporteren en te monitoren. De Commissie is voor een belangrijk deel afhankelijk van de input die vanuit de lidstaten wordt geleverd om bestaande wetgeving aan te passen en te verbeteren, en mee te nemen in haar effectbeoordelingen. Ex ante effectbeoordelingen worden als zodanig uitgebreid en verbonden met ex post evaluaties van wetgeving en relevante nationale instanties dienen aldus actief betrokken te worden en zijn in de beginfase van bijvoorbeeld de aanname van richtlijnen, de implementatie- én evaluatiefase daarvan.

Nieuw én winst is dat niet alleen alle drie de wetgevingsinstellingen deze circulaire visie onderschrijven in het IIA, maar deze visie dus ook lidstaten op hun eigen verantwoordelijkheid wijst in deze verschillende fasen van de beleidscyclus voor het realiseren van betere Uniewetgeving. Dit bouwt voort op de benadering die de Commissie zelf al eerder inzette, in het bijzonder in haar Bekendmaking inzake slimme regelgeving in de EU uit $2010,{ }^{26}$ waarin ze gedeelde verantwoordelijkheid met de lidstaten, de focus op de gehele beleidscyclus en participatie en consultatie als de hoekstenen van 'slimme regelgeving' neerzette. Daarnaast krijgt ook het REFITbeleid dat de Commissie in 2012 lanceerde $\mathrm{e}^{27}$ met het IIA een interinstitutionele grondslag en wordt dit een prominent onderdeel van het jaarlijkse werkprogramma en de politieke dialoog met de andere instellingen voor en na de aanname van het werkprogramma. Via het al op 19 mei 2015 opgezette REFIT-platform moeten de lidstaten ook meer directe invulling aan hun eigen verantwoordelijkheid in deze geven. Dit platform bestaat uit twee permanente groepen; een groep van regeringsvertegenwoordigers (uit elke lidstaat één) en een stakeholdergroep, die bestaat uit vertegenwoordigers uit het bedrijfsleven, de sociale partners, het maatschappelijk middenveld, het Economisch en Sociaal Comite en het Comité van de Regio's. De groepen komen zowel apart als gezamenlijk bij elkaar. ${ }^{28}$

\section{Een sterk constitutionele, geproceduraliseerde} insteek

Beschouwt men het BR-pakket in zijn geheel en in samenhang met het IIA, dan is vooral opvallend de sterke nadruk op het conditioneren van de uitoefening van overheidsgezag in het Europese wet- en regelgevings-

25. Zie hierover ook E.M.H. Hirsch Ballin en L.A.J. Senden, Co-actorship in the Development of European lawmaking. The Quality of European Legislation and its Implementation and Application in the National Legal Order, The Hague: T.M.C. Asser Press 2005.

26. $\operatorname{COM}(2010) 543$ def.

27. $\operatorname{COM}(2012) 746$

28. Zie <http://ec.europa.eu/smart-regulation/refit/refit-platform/index_nl. htm>, laatst geraadpleegd op 29 juni 2016. proces via allerlei procedures, gebaseerd op een breed scala aan juridische beginselen of grondgedachten. Dit betreft in het bijzonder transparantie, subsidiariteit en proportionaliteit, democratische legitimiteit, fundamentele rechten, rechtszekerheid, vereenvoudiging en eenvoud, duidelijkheid, consistentie, loyale samenwerking, coördinatie en verantwoording, gelijkheid van medewetgevers en institutioneel evenwicht. Veel van deze beginselen vormden al de basis van het vroegere wetgevingskwaliteitbeleid van de Unie en blijken nu dus nog steeds sterk richtinggevend voor het BR-beleid. In het IIA is ook duidelijk dat met name de twee laatstgenoemde beginselen leidend zijn geweest bij de gemaakte keuzes en de concrete invulling. Hoe begrijpelijk dit vanuit interinstitutioneel Unieopzicht ook mag zijn, vanuit het perspectief van BR en de inhoudelijke en instrumentele betekenis die daaraan kan worden gegeven, valt daar zeker het nodige op af te dingen (zie hierna, de paragraaf 'Een te beperkte opvatting van betere regelgeving').

Of het nieuwe BR-beleid toegevoegde waarde heeft ten opzichte van het eerdere beleid, hangt daarmee niet zozeer af van de grondleggende beginselen maar van de vraag in welke mate de nieuwe, daarop gebaseerde procedures wezenlijke stappen vooruit betekenen. Daarbij gaat het niet alleen om vooruitgang in theoretische zin, maar ook om de vraag of ze zullen - kunnen - leiden tot vooruitgang in de institutionele praktijk. Als het gaat om de interinstitutionele aanpak aangaande programmering, effectbeoordeling, de coördinatie van het wetgevingsproces, evaluatie van wetgeving en raadpleging, in het bijzonder bij gedelegeerde rechtshandelingen, is zeker belangrijke vooruitgang geboekt en is voorzien in veel meer concrete verplichtingen over en weer tussen de instellingen om elkaar te informeren, in dialoog te treden en rekening met elkaar te houden dan in het oude IIA het geval was. Deze stappen brengen daarmee wel verwachtingen met zich mee dat een betere focus, afstemming, evaluatie, versnelling, enzovoort van het wetgevingsproces zal kunnen worden gerealiseerd. De Commissie heeft met name als het gaat om programmering en raadpleging bij gedelegeerde handelingen zeker ook meer aan autonomie ingeboet dan haar voor ogen stond in het voorstel voor het nieuwe IIA. Als zodanig kan het IIA in vergelijking met zijn voorganger zeker wel worden gezien als een belangrijke, versterkte uitdrukking van gedeelde institutionele verantwoordelijkheid voor beter wetgeven in de Unie.

Desondanks zijn er wel enige aspecten die nog steeds zorgen baren en waar het IIA zich niet in duidelijke termen over uitlaat. Dit betreft onder meer dat van de effectbeoordeling; vanuit oogpunt van efficiëntie, consistentie en doelmatigheid valt het te betreuren dat er niet is gekozen voor een enkel interinstitutioneel instrument en panel daarvoor en dat de tekst vaag is voor wat betreft de uitvoering daarvan door het EP en de Raad. Want wanneer is er sprake van een zo 'substantiële wijziging' van een Commissievoorstel dat een aanvullende effectbeoordeling nodig is? Er blijft dus nog steeds veel ruimte bestaan voor de Raad en het EP om die eigen afweging te maken en zo'n beoordeling achterwege te 
laten. Een problematischere kwestie betreft die van de intransparante trialoog in het kader van de gewone wetgevingsprocedure, ${ }^{29}$ ten aanzien waarvan het IIA slechts stelt dat 'de drie instellingen zorgen voor de transparantie van de wetgevingsprocedures, met inbegrip van een passende afhandeling van trilaterale onderhandelingen'. Het EP heeft hierover in zijn besluit van maart jl. een kritische noot gekraakt. ${ }^{30}$ Vermeldenswaard is in dit verband ook dat Nederland in april 2015 samen met Denemarken, Estland, Finland, Slovenië en Zweden een nonpaper heeft gepubliceerd, ${ }^{31}$ waarin vooral is gefocust op het verbeteren van de transparantie van de EU. Een concrete maatregel die daarin werd voorgesteld om in het IIA op te nemen maar het niet heeft gehaald, betrof het transparanter maken van trialogen bijvoorbeeld door via gezamenlijke bekendmakingen informatie over de uitkomst daarvan te verspreiden en data van trialogen vooraf bekend te maken. Andere bepleite maatregelen ontbreken eveneens, in het bijzonder met betrekking tot het invoeren van een coherent systeem dat erin voorziet hoe en wanneer een Raadsdocument als limité wordt aangemerkt en een aansluiting van de Raad bij het transparantieregister dat de Commissie en het EP al gebruiken, opdat alle wetgevingsinstellingen dezelfde transparantiestandaarden toepassen. De besluitvorming binnen de Raad blijft daarmee nog steeds een hoog black boxgehalte houden, wat vanuit het perspectief van het verbeteren van het vertrouwen van de burger in de EU als een gemiste kans kan worden beschouwd.

Een andere in het non-paper voorgestelde maatregel heeft wel een plek gekregen in het IIA, namelijk de toekomstige creatie van een database, waarin de hele wetgevingscyclus terug te vinden is aan de hand van alle documenten die in de verschillende procedurele stappen van het besluitvormingsproces zijn genomen door de Commissie, de Raad en het EP. Voorts hamerden deze lidstaten ook op de snelle invoering van een register van gedelegeerde en uitvoeringshandelingen en op het houden van experthoorzittingen in dat verband. Daarin komt het IIA dus wel tegemoet.

Maar veranderingen op papier staan niet meteen borg voor daadwerkelijke verandering van de institutionele praktijk. Of de voorziene procedures echt gaan leiden tot meer informatie-uitwisseling, dialoog, coördinatie, transparantie, versnelling en beter geïnformeerde besluitvorming kan dan ook alleen de toekomst uitwijzen. Maar enkele reserves ten aanzien van al te hoog gestemde verwachtingen lijken me wel op zijn plaats. Allereerst is daar de wel zeer grote hoeveelheid aan regels en procedures die in het algehele BR-pakket is voorzien voor de verschillende onderdelen van het pro-

29. Zie hierover onder meer D. Curtin, 'Challenging European Executive Dominance in European Democracy', Modern Law Review 2014, vol. 77, nr. 1, p. 1-32

30. Zie Besluit van het Europees Parlement van 9 maart 2016 over de sluiting van een interinstitutioneel akkoord tussen het Europees Parlement, de Raad van de Europese Unie en de Europese Commissie over beter wetgeven (2016/2005(ACI)), P8_TA-PROV(2016)0081.

31. Te vinden op <www.tweedekamer.nl/kamerstukken/verslagen/detail? id=2015D25665>, laatst geraadpleegd op 21 juni 2016 . ces; hoe realistisch is het van Commissieambtenaren te verwachten dat ze deze allemaal gaan toepassen, gegeven ook uiteenlopende senioriteit en expertise? Daarbij komt dat de personele capaciteit die de Commissie beschikbaar heeft al met al beperkt is en dat een deel daarvan op korte termijn ingezet zal moeten worden voor het regelen van de Brexit. Los daarvan veranderen institutionele praktijken in het algemeen niet gemakkelijk en zijn verschillende factoren daarop van invloed, waaronder cultureel-cognitieve. Deze dragen bijvoorbeeld bij aan het ontwikkelen van een sociale consensus in een organisatie dat zaken op een bepaalde manier gedaan worden en routines op die grond worden geaccepteerd. ${ }^{32}$ Daarbij komt dat de ene instelling er meer belang bij kan hebben om een bestaande praktijk te veranderen door een nieuwe procedure te gaan volgen dan de andere. In dergelijke omstandigheden kan men zich met recht afvragen hoeveel aandrang en stimulans er zal zijn om institutionele patronen en gewoonten daadwerkelijk te veranderen, ook al creëert de Brexit juist ook druk om bepaalde veranderingen te bewerkstelligen.

Een te beperkte opvatting van betere regelgeving Het meest fundamentele punt van kritiek in deze beschouwing komt toe aan welke betekenis eigenlijk moet worden gegeven aan het concept van 'betere regelgeving', aan wie betere regelgeving uiteindelijk ten goede zou moeten komen, en hoe het Uniebeleid in het licht hiervan kan worden beoordeeld.

In de literatuur wordt ' $k$ waliteit' gezien als het product of de dienst die tegemoetkomt aan de verwachtingen van de gebruikers en stakeholders. Evaluatie van kwaliteit betreft niet alleen het eindproduct of de uiteindelijke dienst, maar de totaliteit van de verwachtingen van de gebruiker of ontvanger. Het toezien op kwaliteit betreft daarmee ook het algehele (productie)proces. ${ }^{33}$ Daar waar het concept van 'wetgevingskwaliteit' veel nadruk legt op constitutionele, procedurele, input-legitimiteitsaspecten, voegt het concept van 'regelgevingskwaliteit' een meer doelgerichte dimensie toe aan het regelgevingsproces en aan de resultaten daarvan. ${ }^{34}$ Hiermee komt meer nadruk te liggen op de effectiviteit en efficiëntie van regelgeving en de realisering van beleidsdoelstellingen en daarmee dus ook op output-legitimiteit van het regelgevingsproces. ${ }^{35}$ In dit verband is het dus ook van groot belang om beleids- en regelgevingsdoelstellingen duidelijk te identificeren. Howlett en Rayner stellen dat

32. Zie bijvoorbeeld W.R. Scott, Institutions and Organizations. Ideas, Interests and Identities, Sage 2014 (4e dr.), p. 66-70.

33. Zie bijvoorbeeld J.W. Dean Jr. en D.E. Bowen, Management theory and total quality: improving research and practice through theory development, Acad. Manage Rev. 1994, vol. 19, nr. 3, p. 392-418.

34. Uitgebreider hierover A. Meuwese en L.A.J. Senden, 'European Impact Assessment and the Choice of Alternative Regulatory Instruments', in: J. Verschuuren (red.), The Impact of Legislation. A Critical Analysis of Ex Ante Evaluation, Leiden: Brill 2009, p. 135-174.

35. Zie F. Scharpf, Governing in Europe, Oxford: Oxford University Press 1999. 
'slimme regelgeving zijn plek vindt in een bredere literatuur over de verschuiving van een meer handson, interveniërende bestuursstijl naar bestuur op afstand, "governance" en de wijd verbreide metafoor van overheden die publieke belangen realiseren veeleer via het sturen van complexe netwerken van publieke en private actoren dan via het aansturen van een dure en mogelijkerwijs ineffectieve bureaucratie'. ${ }^{36}$

'Slimme regelgeving' onderkent dus zowel het belang van betrokkenheid van private actoren, en niet enkel via consultaties in een publiek regelgevingsproces, als van het gebruik van een mix van instrumenten, waarbij de specifieke beleidscontext in anmerking wordt genomen. In een dergelijke mix hebben de minst ingrijpende instrumenten de voorkeur, waaronder stimulerings-, informatieve- en anmoedigingsinstrumenten evenals zelf- en co-regulering. Het impliceert ook een zoektocht naar 'nieuwe generatie'-instrumenten ${ }^{37}$ en een focus op hoe verschillende instituties, instrumenten en technieken met elkaar te combineren. Ook de OECD onderkent het belang van alternatieven voor traditionele regulering als een belangrijk instrument om regulering te verbeteren. ${ }^{38}$

Beschouwen we het BR-pakket in dit licht, dan kunnen we allereerst constateren dat hoewel burgers, bedrijven en overheidsdiensten als gelijkwaardige adressaten daarin worden gepresenteerd, in de inhoud ervan vooral de belangen van bedrijven en overheidsdiensten die last ondervinden van overregulering en administratieve lasten centraal zijn gesteld. Zo komt dit uitdrukkelijk in de doelstellingen van het IIA terug en wordt daarin geen enkele inhoudelijke norm, belang of waarde benoemd waar Uniewetgeving aan zou moeten voldoen. Enkel in de preambule wordt in zeer algemene termen gesteld dat de drie instellingen gezamenlijk dienen te verzekeren dat Uniewetgeving 'zich richt op gebieden waar zij voor de Europese burgers de grootste meerwaarde oplevert, de gemeenschappelijke beleidsdoelstellingen van de Unie zo efficiënt en doeltreffend mogelijk verwezenlijkt, [en] het concurrentievermogen en de duurzaamheid van de economie van de Unie worden versterkt'. Een verwijzing naar bijvoorbeeld de sociale dimensie van de Unie ontbreekt in zijn geheel en aan fundamentele rechten wordt enkel gerefereerd in de paragraaf die betrekking heeft op effectbeoordeling. De inhoudelijke focus van het BR-beleid is daarmee eenzijdig ingevuld en weinig concreet in termen van wat het BR-beleid de burger moet c.q. kan opleveren. Het is dan ook begrijpelijk dat veel maatschappelijke organisaties zorgen hebben geuit over de mogelijke gevolgen van het BR-beleid en de

36. Mijn vertaling. M. Howlett en J. Rayner, '(Not so) "Smart regulation"? Canadian shellfish aquaculture policy and the evolution of instrument choice for industrial development', Marine Policy 2004, 28(2), p. 171-184.

37. Zie ook Howlett en Rayner 2004.

38. OECD Rapport 'Industry self-regulation: role and use in supporting consumer interests', March 2015, <www.oecd.org/officialdocuments/ publicdisplaydocumentpdf/?cote=DSTI/CP(2014)4/FINAL\& docLanguage $=E n>$. daarin vervatte kwantitatieve reductiedoelstellingen, vanwege het risico dat dit in zich bergt van deregulering ten koste van bestaande standaarden en niveaus van bijvoorbeeld milieu- en consumentenbescherming en volksgezondheid. Dit heeft zelfs geleid tot de oprichting van de Better Regulation Watchdog, om te bewaken dat het BR-beleid geen averechtse effecten sorteert voor burgers, consumenten, werknemers en voor het milieu. In dit netwerk zijn 66 belangenorganisaties en vakbonden verenigd, die tezamen tientallen miljoenen burgers vertegenwoordigen. ${ }^{39}$ In de brief van de Eerste Kamer aan de Commissie is ook de zorg geuit dat het BR-beleid economische belangen voorop zet en milieu- en sociale aspecten minder aandacht krijgen daarin en dat het beleid meer ten goede lijkt te komen aan machtige deelbelangen dan aan de maatschappij als geheel.

Wat de instrumentele mix betreft, kan worden geconcludeerd dat het BR-beleid een zekere discrepantie of ambivalentie laat zien. Enerzijds heeft de Commissie een belangrijke stap vooruit gezet door zich in de BRMededeling niet alleen te committeren aan het gebruik van alternatieve instrumenten, maar in de BR-richtsnoeren en in Toolbox \#15 ook criteria te formuleren voor de operationalisering daarvan in de praktijk. Daarbij heeft het ook de beginselen voor betere co- en zelfregulering onderschreven die enige jaren geleden door DG Connect zijn vastgesteld. ${ }^{40}$ Anderzijds laat het IIA in dit opzicht echter een stap achteruit zien, door alle uitvoerige bepalingen die het IIA uit 2003 hierover bevatte, en specifiek die over het gebruik over zelf- en co-regulering, geheel en al te schrappen. Enkel in het kader van effectbeoordeling wordt in algemene zin opgemerkt dat deze alternatieve oplossingen in kaart moeten brengen ${ }^{41}$ en verder worden alleen harmonisering en wederzijdse erkenning genoemd in het kader van vereenvoudiging van wetgeving. De vraag is hoe dit met elkaar moet worden gerijmd. Op zijn minst kan geconcludeerd worden dat de drie instellingen geen eenduidige, gezamenlijke visie hebben geformuleerd ten aanzien van het belang en het gebruik van een instrumentele mix om betere regelgeving te bewerkstelligen en dat alleen de Commissie zich aan dat uitgangspunt heeft verbonden. Deze omissie in het IIA en de sterke focus daarvan op beter wetgeven (zoals ook uit de titel blijkt), onderstreept andermaal dat het IIA bovenal het institutionele evenwicht tussen de drie instellingen in het Uniewetgevingsproces beoogt zeker te stellen en niet als zodanig is gericht op 'betere regelgeving' in een bredere betekenis.

39. <www. betterregwatch.eu>.

40. Door de Community of Practice on Better Self- and Co-regulation, zie $<$ https://ec.europa.eu/digital-single-market/en/community-practicebetter-self-and-co-regulation-0>

41. Volgens Baldwin 2007 lenen effectbeoordelingen zich echter niet goed voor de beschouwing van reguleringsalternatieven en nog minder voor het bewerkstelligen van een instrumentele mix, omdat dergelijke beoordelingen meer toegespitst zijn op het meten van effecten van traditionele command-and-control wetgeving. Ook de Raad voor effectbeoordeling heeft beschouwing van reguleringsalternatieven als een zwak punt geïdentificeerd. Zie hierover Meuwese en Senden 2009. 


\section{Tot besluit}

Tegen de achtergrond van de huidige kritische politiekmaatschappelijke discussie over de Europese Unie, nu scherp gemarkeerd door de aanstaande Brexit, maar ook in het licht van de bredere, inhoudelijke en instrumentele betekenis die aan BR kan worden toegekend, kan het BR-beleid van de Unie wel als too little, too late worden bestempeld. De insteek van dat beleid is vanuit een constitutioneel en institutioneel perspectief van machtsevenwicht best begrijpelijk, evenals de focus op het terugdringen van regels en administratieve lasten, juist vanuit de bezwaren die het VK maar ook andere lidstaten hebben geuit. Maar voor veel burgers is dat een vervan-hun-bed show en niet voldoende ter behartiging van hun belangen en behoeften. Veel Britse nee-stemmers lijken de EU er nu toch vooral voor te hebben afgestraft dat ze niet hebben meegeprofiteerd van de economische ontwikkeling en kampen met sociale uitsluiting, werkloosheid en onvoldoende onderwijs. ${ }^{42} \mathrm{Die}$ inhoudelijke, materiële dimensie ontbeert het Unie BRbeleid nu grotendeels, althans deze is in zeer vage termen gehuld of nogal ondergesneeuwd in Commissieprocedures. Daarin schuilt de uitdaging voor de Europese regeringsleiders en Uniewetgever in de toekomst; niet de belangen en bevoegdheden van de Unie-instituties, lidstaten en bedrijven dienen voorop te staan in de vormgeving van het Uniebeleid, maar de burger en zijn problemen, behoeften en belangen. Ook het BR-beleid zou vanuit die grondgedachte moeten vertrekken en daar de bakens voor uit moeten zetten. Dat vergt een nogal fundamentele koerswijziging waarbij niet lastenreductie voor bedrijven en lidstaten voorop wordt gesteld als centrale doelstelling, maar hoe de EU tot een vormgeving van beleid komt die recht doet aan de belangen van alle burgers, met name ook degenen die nu de meeste lasten of keerzijden ondervinden van het Europese integratieproces. Lastenreductie en het anpakken van overregulering zou in functie van die bredere maatschappelijke doelstelling moeten worden gezien.

42. Zie bijvoorbeeld R. Fevre, 'More in hope, less about immigration. Why poor Britons really voted to leave the EU', te vinden op: <https:// theconversation.com/more-in-hope-less-about-immigration-why-poorbritons-really-voted-to-leave-the-eu-61971>, laatst geraadpleegd 2 juli 2016. 
LIVE WEBINARS EN VIDEO'S INCLUSIEF PO-PUNTEN

- TOPDOCENTEN

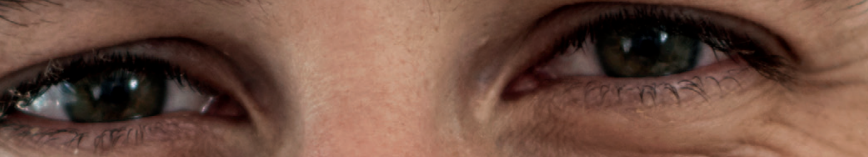
1)

- VANAF UW EIGEN WERKPLEK OF THUIS - VIDEO'S 24/7 BESCHIKBAAR WWW.LAWATWEB.NL 


\section{Bju TIJDSCHRIFTEN ONLINE}

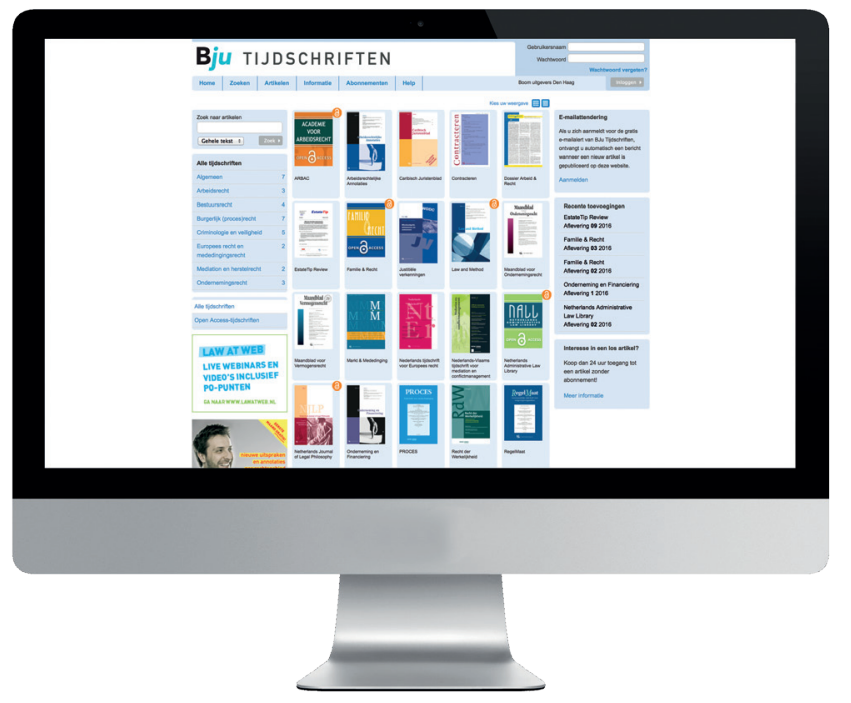

$$
\begin{aligned}
& \text { OOSK } \\
& \text { LSSARTIKELEN } \\
& \text { VERKRIJGBAAR! }
\end{aligned}
$$

- bevat ruim 14.000 wetenschappelijke artikelen;

- bestaat uit meer dan 30 tijdschriften;

- houdt u op de hoogte met de gratis e-mailattendering

U kunt een abonnement nemen op één of meer tijdschriften, maar ook op de gehele portal (all-in). Daarnaast zijn artikelen zonder abonnement verkrijgbaar.

Interesse in een all-in-abonnement of een langere proefperiode? Neem dan contact op met onze salesafdeling via salesवbju.nl of bel met 070-330 7092. 
